Max-Planck-Institut für demografische Forschung

Max Planck Institute for Demographic Research

Doberaner Strasse 114 - D-18057 Rostock · GERMANY

Tel +49 (0) 3812081 - 0; Fax +49 (0) 3812081 - 202;

http://www.demogr.mpg.de

MPIDR WORKING PAPER WP 2001-019

JULY 2001

\title{
Childcare and Fertility in (Western) Germany
}

Karsten Hank (hank@ demogr.mpg.de)

Michaela Kreyenfeld (kreyenfeld@demogr.mpg.de)

This working paper has been approved for release by: Hans-Peter Kohler (kohler@ demogr.mpg.de) Head of the Research Group on Social Dynamics and Fertility

C) Copyright is held by the authors.

Working papers of the Max Planck Institute for Demographic Research receive only limited review. Views or opinions expressed in working papers are attributable to the authors and do not necessarily reflect those of the Institute. 


\title{
Childcare and Fertility in (Western) Germany
}

\author{
Karsten Hank and Michaela Kreyenfeld *
}

\begin{abstract}
This paper analyzes the relationship between children's day care and fertility in Germany. First, different modes of childcare are discussed with regard to their availability and costs. We then estimate the impact of having access to public day care and care in social networks on first birth probabilities of western German women in the 1980s and 1990s. The empirical analysis does not reveal any statistically significant effect of childcare availability on fertility. We conclude that the overall institutional constraints of day care in (western) Germany prevent the compatibility of childrearing and employment, thereby forcing women to choose between a continuous employment career or childlessness.
\end{abstract}

Keywords: childcare, fertility, multilevel analysis, Germany.

\footnotetext{
* The views expressed in this paper are our own. They do not necessarily reflect the views of the Max Planck Institute for Demographic Research.

Authors' correspondence address: Max Planck Institute for Demographic Research, Doberaner Str. 114, 18057 Rostock, Germany. Telephone: +49-381-2081-163. Fax: +49-381-2081-463. Email: hank@demogr.mpg.de.
} 


\section{Introduction}

In many western countries, the public provision of day care for children is part of broader family policies that are often designed to foster the compatibility of female employment and childrearing (e.g., GuSTAFFSON and STAFFORD 1992, MEYERS ET AL. 1997). Numerous studies have shown that affordable prices and a sufficient availability of day-care centers facilitate greater participation of mothers in the labor market (e.g., ANDERSON and LEVINE 2000, STOLZENBERG and WAITE 1984). While economists usually focus on childcare costs (e.g., BlAU and RoBins 1989, CONELly 1992), it has been argued that in the presence of market failure and in highly regulated contexts the availability rather than the affordability of childcare should be crucial for a mother's employment decision (e.g., Gordon and Chase-LANSDAle 2001, KreYenFELD and HANK 2000).

Since the (western) German day-care system is found to be highly ineffective in enabling mothers to participate in the labor market, mothers often have to rely on 'patchwork childcare arrangements', where children are subject to a multitude of care arrangements (e.g., TIETZE and RossbaCH 1991). Apart from parental care, one may distinguish between care in day-care centers, care in and by social networks, or care by private child-minders, which all differ by price, availability, and quality. Therefore, parents (as well as researchers) need to consider a complex bundle of possible childcare arrangements and their specific advantages and disadvantages.

The availability of adequate day care opportunities may not only affect a woman's labor supply, but also her fertility decisions. Although this issue is often acknowledged implicitly, it has been rarely addressed directly in the literature. One of the few 
exceptions is a study by LEHRER and KAWASAKI (1985), which suggests that the availability of care by relatives may increase US parent's desire to have another child. More recently, KRAVDAL (1996) finds a stimulating effect of an increasing supply of public day care for children aged 0 to 3 on Norwegian women's probability to advance to parity three. This effect, however, becomes insignificant when aggregate female employment is accounted for in the model, and disappears at coverage levels above 10 percent. Finally, ten percent of the respondents in a sample of Detroit-area mothers report a negative influence of childcare constraints on the timing and number of their children (MASON and KUHLTHAU 1992: 539f.). The negative effect of childcare problems on women's labor supply, however, is found to be even stronger: every third interviewed woman reports that problems with childcare constrained their employment.

The present paper investigates the role of the availability of childcare for fertility decisions in Germany. In Section 2, we discuss the relationship between female employment, children's day care, and fertility in general. Section 3 provides a concise overview of day care for children in Germany. Section 4 describes the empirical procedure. Individual level data on women living in western Germany during the period 1984 to 1995 are taken from the German Socio-Economic Panel (GSOEP), which we link with official statistics on the regional day-care provision. Due to data limitations, we are unfortunately not able to include the eastern states of the Federal Republic into the multivariate analysis. Applying multilevel discrete-time logit models, we estimate the impact of the availability of public day care and informal private day care arrangements (i.e., social networks) on the transition to the first child (Section 5). Conclusions are presented in $\underline{\text { Section } 6}$. 


\section{Female employment, childcare, and fertility}

From the mid-1960s onwards, the fertility rates of basically all industrialized countries declined rapidly, reaching a persistent below-replacement level soon after. Simultaneously, an increase in the age at first birth and in the ratio of childlessness could be observed. It has often been argued that the underlying cause of this development is closely related to women's increasing educational attainment, their growing labor market participation, and higher career aspirations. Analyzing macro level data from the US, BUTZ and WARD (1979), for example, show that female wages are negatively correlated with fertility rates. Also at the micro level, many studies find a negative correlation between female wages or female education on one hand, and fertility on the other (e.g., Merrigan and St. Pierre 1998, Heckman and Walker 1990). HiRSCHMAN (1994: 222) concludes from a review of the literature that one "of the most consistent findings [...] is a negative relationship between women's education and fertility, both at the individual and the aggregate level".

Since even in 'modern' societies primarily women are responsible for rearing children, they usually cannot pursue a regular employment career once they have become a mother. Thus, BREWSTER and RiNDFUSS (2000: 271) argue that "the inverse association [...] between fertility and women's labor force activity reflects the incompatibility between caring for children and participation in economically productive work that typifies industrialized societies." However, the empirical evidence for a negative correlation between women's employment and fertility is far less consistent than has often been stated. In recent years, there have been several studies that even report a positive correlation between female education / female employment 
and fertility (e.g., Ahn and Mira 1999, DeWit and Ravanera 1998, Hoem 2000, KREYENFELD 2001). These findings possibly indicate that "in some countries [...] women have found ways to combine work and child rearing, and in others they have not” (BREWSTER and RINDFUSS 2000: 279).

Apart from the ambiguous empirical evidence, the theoretical reasoning on the employment-fertility nexus may lead to ambiguous predictions, too (e.g., BLAU and RoBins 1989: 288, MACUNOVICH 1996, RindFuSS ET AL. 1996: 280). Since more highly educated women are likely to earn higher wages than their less educated contemporaries, they will encounter higher opportunity costs if they withdraw from the labor market after childbirth. It is therefore often argued that they should be less likely to have children. However, given flexibility in work schedules, egalitarian gender roles, and sufficient non-parental (usually non-maternal!) childcare opportunities, women do not necessarily have to interrupt their employment career (e.g., ELLINGSÆTER and RøNSEN 1996). Although they may encounter a "wage penalty for motherhood" (BUDIG and ENGLAND 2001), women who combine childrearing and employment have a higher income than those who stay at home. This reduces not only the relative financial burden of out-of-home care, but working mothers are also better able to afford having (more) children, considering that they have larger economic resources to support a family (e.g., HUININK 2001). In other words, high female employment rates might well be compatible with high fertility rates, provided that the interplay between the labor market, the family, and the state constitutes a favorable social context (see ESPINGANDERSEN 1999). 
A key question therefore becomes under which institutional conditions parents are willing and able to purchase non-maternal care for their children ${ }^{1}$, and whether and how this alleviates the compatibility of childrearing and employment. At this point, the standard micro-economic framework does not provide any further clues, but solely refers to the costs of childcare and the elasticity of the demand for care. While reducing children's day care to the question of prices and costs makes the childcare issue easy to handle, it ignores potentially important institutional constraints, which are likely to hinder women from combining childrearing and having a working career. Thus the economic approach to the childcare-fertility issue neglects a whole set of other questions that deserve thorough consideration: How far does the availability of public day care facilitate the compatibility of childrearing and employment? Which role do private day-care arrangements play? What is the importance of care in social networks (e.g., relatives) compared to institutional care? To what extent do couples take into account the variety of childcare options, when they plan to have children?

In most cases, parents will have to consider a complex bundle of possible childcare arrangements. We suggest to distinguish particularly three modes of care, which differ substantially with regard to their availability and costs: ${ }^{2}$

(1) Social networks: Care for a child can be provided by social networks, which may

\footnotetext{
${ }^{1}$ The (social) acceptance of different forms of non-parental care is an issue that plays an important role in this context as well. Parents might be concerned that out-of-home day-care could harm the wellbeing of their child, e.g. because the quality of public day-care is perceived as insufficient. Moreover, parents are often confronted with strong normative expectations that prevent them from using out-of-home care, particularly for children at younger ages (e.g., BERTRAM and DANNENBECK 1991: 104, RINDFUSS and BREWSTER 1996: 277).

${ }^{2}$ Only the quantitative aspect of day care is considered here. For a discussion concerning the quality of children's day care, see e.g. BLAU and HAGY (1998).
} 
consist of friends, neighbors, or relatives. Particularly a child's grandparents often play a major role as a provider of care in social networks (see below). However, only couples who live in close proximity to their own parents, for example, can use the child's grandparents as a day-care provider. Care in social networks is usually free of charge.

(2) Institutional care: In European countries, institutional day care, such as the German Kindergarten, is mostly public. Day-care centers are run by the local municipality or by publicly subsidized NPOs, which leads to relatively low childcare costs. Private (i.e. commercial) day-care centers, on the other hand, are usually of minor importance only. The availability of public day care differs widely between and within countries, i.e. the chance to get access to children's day care and to reconcile childrearing and employment are not evenly distributed across regions.

(3) (Private) child-minders: Care by private child-minders is in most countries less regulated than care in day-care centers, thereby constituting a relatively informal childcare arrangement. Child-minders typically take care of the child at home and are not required to fulfill strong quality regulations. Since the use of private childminders is usually not subsidized, the costs of care are relatively high, if compared to other childcare modes.

Finally, one might want distinguish between paternal care and maternal care. Generally it is the female partner who is supposed to give up market work to take care of the children (see JOSHI 1998 for a recent discussion). This might be the result of an intra-family bargaining process, which assigns the childcare responsibilities to the person with the lower market wage rate (e.g., OTT 1992). On the other hand, the traditional division of household responsibilities might just as well be an indicator for 
the persistence of traditional gender roles (e.g., ENGLAND AND FARKAS 1986). The more likely it is that the father takes over childcare responsibilities, the less strong should be the negative correlation between fertility and female employment (see CASPER and O'CONNELL 1998 for a study on married fathers as childcare providers in the US). In a society, where childrearing is still considered to be primarily the mother's responsibility, though, the absence of sufficient non-maternal day-care opportunities almost inevitably leads to a situation, where many women have to choose between having a child or proceeding an employment career. In the following, we discuss the above-mentioned childcare arrangements and their specific characteristics in greater detail for Germany.

\section{Children's day care in Germany}

\subsection{Public day care in western Germany}

Generally speaking, the German day-care system is characterized by a high level of quality regulation and a dominance of publicly provided childcare slots (see KREYENFELD ET AL. 2001 for a detailed analysis).

In western Germany, part-time care in Kindergarten, i.e. for pre-schoolers aged 4 to 6 , became established in the 1970s, and since 1996 all children aged 3 to school-age are entitled to a slot in a public day-care center for half of the day (COLBERG-SCHRADER and ZEHNBAUER 1996). However, while in 1999 about 85 percent of the pre-school children attended a Kindergarten (as compared to 30 percent in 1960), care for children aged 0 to 3 in the so called Krippe, and care for school-age children in the Hort has remained at an extremely low level of clearly less than 10 percent in western Germany 
(see Table 1). The same is true for full-time care, which is used by only 20 percent of the children in Kindergarten, and is virtually non-existent for younger children or those who are of school-age.

[Table 1 about here]

Distinct regional variations in supply can be observed, which reflect the fact that the provision of public day care is financed and planned by the municipalities. While differences in the supply of care in Kindergarten are relatively modest, rural regions are generally found to be at a clear disadvantage concerning the public provision of day care, particularly regarding slots for infants and for school-age children (KREYENFELD and HANK 2000, TIETZE ET AL. 1993). Either the municipality itself provides day-care slots, or it allocates subsidies to non-profit organizations, which in turn provide day-care facilities. Admission policies and fees (Elternbeiträge) do not differ substantially between the latter and public day-care centers. In both, subsidies cover up to 90 percent of the operating costs, and the costs of care to parents are relatively low (see Table 2$)^{3}$, particularly since day-care fees should be charged according to the household income of the parents (KREYENFELD ET AL. 2001).

[Table 2 about here]

\footnotetext{
${ }^{3}$ Reliable data on the actual amount of day-care fees that parents have to pay are hard to come by (e.g., BocK and TimMERMANN 2000). In most Bundesländer, day-care fees are fixed by the local day-care providers. Only Nordrhein-Westfalen and the city-states Berlin, Bremen, and Hamburg specify the amount of day-care fees at the level of the federal land. Parents in Nordrhein-Westfalen with a yearly household income of 72,000 to 96,000 DM currently pay 113 DM for the Hort, 276 DM for the Krippe and 87 DM for all-day care in the Kindergarten per month (Gesetz über Tageseinrichtungen für Kinder, §26,1).
} 
The origin of present-day (western) German childcare policies can be traced back to the educational reform (Bildungsreform) of the 1960s and 1970s, i.e. public day care in its current form is primarily designed to provide high-quality care that educates children and contributes to creating equal opportunities for them. Childcare policies in (western) Germany are still not designed to foster the compatibility of the mother and worker role. This is not only reflected by the lack of reliable care for children who attend primary school (which are open in the morning hours only and do not start or end the same time every day), or the rigid opening hours of most Kindergartens, which not even allow mothers to work part-time, but also in the 'generous' parental leave regulations, which allow mothers (and in principle also fathers) to stay home and care for the child until it is three years of age.

\subsection{Public day care in eastern Germany}

Between western and eastern Germany, profound differences in the provision as well as in the use of public day care have continued to exist after unification in 1990 (HANK ET AL. 2001). Not only is the provision of slots for infants and school-age children many times higher in the eastern Bundesländer, but also full-time care is still widely available (see Table 1).

This finding is somewhat surprising, given the apprehension that the taking over of the western German political, legal, and economic system would be accompanied by a clearly reduced availability, and substantially increasing costs of childcare in the East (e.g., KISTLER ET AL. 1993). Throughout the history of the GDR, the central government strongly supported and heavily subsidized institutional day care for children of all ages, 
primarily driven by the economic necessity to establish the compatibility of childrearing and female employment. After unification, though, the local municipalities became responsible for running and financing childcare, which caused great concern, since it was unclear whether the municipalities would be able to bear this burden.

However, although many day-care facilities were shut down, children's day care has not moved "from the public to the private sphere" (ADLER 1997: 44). One main reason for the sustained high provision of public day care in the eastern Bundesländer is the dramatic decline in birth rates in the first years after unification (e.g., KREYENFELD 2000). Moreover, it has been argued that in the years following unification high female unemployment rates reduced the demand for out-of-home care (ENGELBRECH and JUNGKUNST 1998).

We have argued elsewhere (HANK ET AL. 2001, KREYENFELD and HANK 2000, KREYENFELD and WAGNER 2000) that - at least in the long run - one can expect the eastern German municipalities to further reduce the number of childcare slots. Eastern German mothers would then no longer be in a better position than their western counterparts to combine childrearing and gainful employment. This means that they, too, will either have to give up their employment career altogether, forgo parenthood, or search for some sort of (additional) private day-care arrangement.

\subsection{Alternative modes of care}

Apart from public day care, the availability of children's day care in social networks or by private child-minders plays an important role for facilitating the compatibility of childrearing and employment. Regarding the restricted supply of public day care, such alternatives should be particularly relevant in western Germany. However, even in 
eastern Germany with its high coverage of public day care, social networks might still be of some importance, e.g. for taking the children to the day-care center or for taking care of the very young children.

[Table 3 about here]

Table 3 displays the use of supplementary childcare arrangements in Germany for the year 1997. It shows that up to 40 percent of all women, and even half of the working mothers regularly rely on relatives or friends as additional providers of care. From the 1996 wave of the GSOEP as well as from other surveys (e.g., ENGELBRECH and JUNKUNST 1998) we know that care by relatives is in the first place care by the child's grandparents. Child minders (Tagespflege) or private day-care centers only play an inferior role in Germany.

Particularly for western Germany, it is surprising that no private childcare market has evolved (yet), considering the limited supply of public day care. One likely reason is the German institutional set-up, where the government is reluctant to promote a private market for child-minders and private providers of day care face high market barriers of entry (see KREYENFELD and HANK 2000, KREYENFELd ET AL. 2001, SPIESS 1998 for a detailed discussion).

\subsection{Interim conclusion}

Given a generally low coverage level and a dominant position of subsidized public daycare providers in (western) Germany, the compatibility of women's employment and fertility should rather depend on the (local) availability of children's day care (either 
institutional or in social networks), than on the costs of day-care arrangements. In a multivariate analysis, we will therefore analyze the impact of the availability of public care and care in social networks on the transition to the first child in western Germany. Due to data limitations, we are unfortunately not able to incorporate the eastern states into the empirical analysis.

\section{Empirical procedure}

\subsection{Data and variables}

\subsubsection{Data source and description of the sample}

The individual level data used in this paper were made available by the German SocioEconomic Panel Study (GSOEP) at the German Institute for Economic Research (DIW Berlin) (see SOEP GROUP 2001 for a description of the dataset). The survey was started in the western states of Germany and is conducted annually since 1984. The GSOEP currently provides longitudinal socio-economic information on more than 7,000 households (including an oversample of foreign-headed households) and 14,000 individuals.

Just recently it has been made possible to link all waves of the GSOEP data with information on the respondents place of residence. The so called 'GSOEP-Geocode' refers to Raumordnungsregionen, i.e. functional-spatial units defined by the Federal Office for Building and Regional Planning (BBR). Since the boundaries of the Raumordnungsregionen have been newly defined in 1996, a longitudinal analysis is only possible for periods before or after that year (see BBR 1999). Unfortunately, the GSOEP-Geocode does not provide regional day-care provision rates. This information 
is therefore taken from the DJI Regionaldatenbank, which includes information on the provision of public day-care for the years 1986 (western Germany only) and 1994 at the district (Kreis) level. ${ }^{4}$ The Kreis level data are then aggregated to fit the respective Raumordnungsregion. Since in the period 1993 to 1995 the eastern German districts were re-organized and their number was reduced from 215 to 113 , it is not possible to assign the Kreis information for the year 1994, which already refers to the 'new' districts as of 1996, to the 'old' Raumordnungsregionen (1990-95).

Thus, only information on the 75 western German Raumordnungsregionen for the years 1984 to 1995 is used in this paper. Moreover, only respondents from the two original GSOEP subsamples are included in the analysis, i.e. western Germans and foreigners from Greece, Italy, Spain, Turkey, and former Yugoslavia, who already lived in Germany in 1984. Our final sample consists of 2,474 women who are observed from age 20 onwards. The upper age limit is 35 years. Since each individual is allowed to contribute multiple observations (see Section 4.2), this leads to 10,451 individual records. The number of observed first births in the period 1984 to 1995 is 836 . Further descriptive sample statistics are displayed in Table 4.

[Table 4 about here]

\section{$\underline{4.1 .2 \text { Description of the variables }}$}

- Dependent variable

The binary dependent variable equals one in case of the occurrence of a first birth within a one-year interval in the period 1984 to 1995.

\footnotetext{
${ }^{4}$ See $h t t p: / / w w w . d j i . d e / 2 \_r d b / d e f a u l t . h t m$ for more information.
} 
- Socio-demographic control variables

Education is treated as a time-varying covariate, measured by a set of binary variables, indicating the respondent's highest educational degree at the time of the survey in each year. It is distinguished between being in education, having no degree, a vocational degree (reference category), or a university degree. Since a non-linear effect of age is assumed, age and age squared are used in the regression.

The woman's marital status enters the regression as a time-varying binary variable, indicating whether the woman is married at the time of the interview. As a control for possible differences in the fertility behavior of native Germans and foreigners, a time-constant binary variable indicating whether the respondent belongs to subsample B (immigrants from Greece, Italy, Spain, Turkey, and former Yugoslavia) of the GSOEP is included.

\section{- Childcare variables}

Many childcare arrangements partly consist of care by relatives, often provided by grandparents (see Table 1). Such arrangements can only be realized, if the grandparents live within a reasonable distance of the child's place of residence. To indicate the potential availability of a family network for childcare purposes, we use a binary variable that equals 1 , if the woman and her parents (either father or mother) live in the same town, 0 otherwise. Unfortunately, the GSOEP provides this information for the years 1991 and 1996 only. We assign the 1991 value to all previous years, and the 1996 value to all years from 1992 onwards, i.e. we treat the variable as being time-constant within each of these two periods. For all respondents who did not participate in the survey in 1991 or 1996, respectively, the variable is set to 0; a flag variable in the regression controls for these imputed values. 
To address the role of institutional childcare for fertility and employment decisions properly, one should ideally take into account not only the raw number of slots being available, but also information on the proximity of day-care centers, their opening hours, and whether care is provided during lunchtime and school holidays. As far as these data exist at all, they are hard to come by. Thus, the availability of public day care in the woman's region of residence is measured here simply by a binary variable that equals 1 , if the provision of slots for children aged 0 to 3 is above the western German median value, 0 otherwise. ${ }^{5}$ Since regional childcare provision rates are available for the years 1986 and 1994 only, the observation period is divided into two parts, lasting from 1984 to 1989 , and from 1990 to 1995 , respectively. While the variable is assumed to be time-constant within each of the two periods, it may change its value between the first and the second part of the observation period.

In 1994 the western German median supply of public care for children aged 0 to 3 was 17 slots per 1000 children of the respective age group (at the district level). The by far highest provision rates were found in (West-) Berlin (191/1000) and Hamburg (112/1000). We consider the provision of slots in the so called Krippe to be an appropriate indicator of the general childcare policy in a region. Moreover, care for an infant constitutes a much more immediate issue for parents than care for an older child. We are aware of the fact that mothers are often confronted with social expectations to stay at home while the child is very young (e.g., BERTRAM and DANNENBECK 1991), and that there are family policies in Germany that may discourage mothers to (re-)enter the labor market soon after a birth (e.g. parental leave regulations, or the system of

\footnotetext{
${ }^{5}$ Specifications using a continuous measure of the childcare provision, or including day care for children of Kindergarten age (4 to 6), have not provided any additional insights.
} 
income splitting). However, women with a high preference to engage in market work, for instance, heavily depend on the possibility to have their child being cared for already at a very early age.

\section{2 (Multilevel) Discrete-time logit models}

The transition to the first child is considered here as a life-course event. Since our data are observed annually, we cannot treat them as if they were continuous, which most methods developed for the analysis of event histories assume. Therefore, a discrete-time model is applied (e.g., ALLISON 1982, YAMAGUCHI 1991).

The setup for discrete-time models is much like that for the case of continuous time, except for the assumption that time can only take positive integer values. It is supposed that a sample of $n$ independent individuals is observed, beginning at some starting point $t=0$. The observation ends at time $t_{d}$, i.e. either when the event occurs, or when the observation is censored. A common choice to specify how the discrete-time hazard rate is determined, is the logistic regression function (ALLISON 1982: 72). If the conditional probabilities that an event occurs at time $t$, given that it has not already occurred, are sufficiently small $(<.10)$, the logit model provides a good approximation to the continuous time proportional hazards model (YAMAGUCHI 1991: 18, 42).

The discrete-time logit model estimates the effect of a number of covariates on the $\log$ of the odds of the event. In the present case, the log odds that a woman experiences a first birth within the one-year interval $t$ is

$$
\log \left[p_{i j t} /\left(1-p_{i j t}\right)\right]=b_{0}+b_{1} x_{i j}+b_{2} z_{i j t}+u_{0 j}
$$

where $p_{i j t}$ is the probability of individual $i$ in region $j$ to have a birth in year $t, b_{0}$ is the intercept constrained to be equal across all years, $x_{i j}$ is a vector of time-constant 
explanatory variables, $z_{i j t}$ is a vector of time-varying explanatory variables at time $t$. Since a birth of a specific order is a non-repeatable event, no individual level unobserved heterogeneity factor can be identified. However, a regional level random component $u_{0 j}$, which is assumed to be normally distributed with the expected value 0 and the variance $\sigma_{u}^{2}$, is included to account for the multilevel structure of some of the models estimated here.

If individual and aggregate level variables are jointly analyzed in a single statistical model, the standard assumption of independent disturbances is critically violated, which may result in inefficient estimates of the macro level parameters and downwardly biased estimates of their standard errors (e.g., HOX and KREFT 1994). To avoid this, a regional random term is introduced here, where the same $u_{0 j}$ applies to all observations in a particular region. It captures otherwise unobserved regional effects and accounts for the correlation between individuals nested within the same context. See GuO and ZHAO (2000) for a detailed discussion of multilevel modeling for binary data.

Different from conventional logistic regression analysis, discrete-time logit models use multiple observations for each individual in the sample. This means that each time unit during which an individual is observed contributes a separate observation to the input data. For each of these observations, the dependent variable is coded 1 if the event occurs, 0 otherwise. The results of the logistic regression may then be exponentiated to obtain odds ratios, which can be interpreted in the sense that, controlling for other covariates, an increase in one unit of $x_{i j}$ increases (or decreases) the odds of having the event $\exp \left(b_{1}\right)$ times. 


\section{Regression results}

For the estimation, a strategy of stepwise inclusion of variables is applied. First, a regression with just the socio-demographic control variables is run (Model 1), then the childcare variables are introduced (Models 2 and 3).

In all of the main effects models, i.e. without consideration of interactions between the explanatory variables, the coefficients of the control variables come out with the anticipated signs (see Table 5). To begin with, the age function has a concave shape and is highly significant. Turning to the educational variables, we find that compared to women with a vocational degree, being in education strongly reduces a woman's propensity to have a first birth during the observation period. Having a university degree, on the other hand, increases first birth risks, although the effect is only weakly significant, if at all. Both findings are consistent with other studies on the role of female educational attainment for first births (e.g., BLOSSFELD and HUININK 1991, RINDFUSS ET AL. 1996). Women tend to postpone the first birth until they completed their education. Since college educated women are usually older when they finish education, they might be under greater 'time pressure' to have their first child. Also as expected, the risk of married women to experience a first birth is many times higher than for the unmarried.

Adding the childcare variables to the regression, i.e. the indicators of a family network and the regional provision of slots, does not change the results in any substantial manner. The childcare variables have no statistically significant impact on a woman's probability of having a first birth in the time period under consideration. The 
standard deviation of the regional random effect $\left(\sigma_{\mathrm{u}}\right)$ turns out to be practically zero, indicating that no potentially relevant unobserved contextual effects are present. $^{6}$

[Table 5 about here]

In addition to these main effects models, we interact the childcare variables with the woman's educational attainment (Models 4 and 5). The assumption underlying these interaction models is that - given traditional gender roles - the impact of children's day care on fertility depends on women's 'career orientation'. A woman who is willing to give up or interrupt her employment career will be less concerned about her childcare options. However, the higher her career orientation, the more important is the availability of children's day care. In line with other studies (e.g., BLOSSFELD and HUININK 1991), we use a woman's educational attainment as an indicator for her career orientation. To allow the influence of childcare options to vary by educational attainment, we interact the variable for having a university degree with the indicators of a family network and the regional provision of slots.

[Table 6 about here]

Since the results of the socio-demographic control variables remain basically unchanged, only the results of the interaction variables, i.e. childcare and education, are reported in Table 6 . We find no particular effect of the availability of day care for

\footnotetext{
${ }^{6}$ See HANK (2001) for a detailed study of regional social contexts and fertility in western Germany. Particularly for the transition to the first child, the author finds no autonomous influence of contextual characteristics. If second births are considered, though, the analysis reveals at least some (weak) 'footprints' of an effect of the regional social context.
} 
women with a university degree. Furthermore a model that includes an interaction between the two childcare variables was estimated (not shown here). Using this specification neither provided any conclusive evidence for an effect of day-care provision. Thus we have to conclude that in none of our model specifications childcare variables exhibit any statistically significant impact on the transition to the first child in western Germany. ${ }^{7}$

\section{Summary and concluding discussion}

With the increase in female employment rates and women's growing labor market orientation, the role of children's day care has gained substantial importance for the analysis of fertility decisions. Given that women's emancipation and - as a consequence - their career orientation are part of an irreversible process of social, demographic, and ideational change (e.g., LESTHAEGHE 1995), higher fertility rates can only be expected, if the incompatibility between childrearing and employment is resolved.

In this paper, we argue that couples need to consider a complex bundle of possible childcare arrangements, which is necessary to reconcile women's employment and childrearing. We suggest to distinguish between (public) day-care centers, (private) child-minders, and care in social networks, which all differ with regard to their

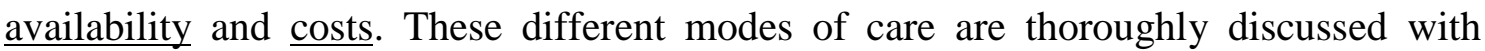
reference to the current German day-care regime, where we find a relatively broad coverage with public day care in the eastern states, and a low coverage with full-time

\footnotetext{
${ }^{7}$ We also tested all of the above models for the progression to parity two (not shown here). These estimates confirm our findings for the first child.
} 
care and care for infants and school-age children in the western states. While a private market for day care does virtually not exist, social networks (particularly the grandparents) play a substantial role as a provider of care. Since the latter usually provide 'free' care, and public day care is highly subsidized, the childcare costs for German parents can be treated as rather negligible for fertility and employment decisions.

In a multivariate analysis, we estimate the impact of the availability of public day care and care in social networks on fertility, focussing on the transition to the first child in the western states of Germany. Several specifications are tested, including models with interactions between the availability of care and the woman's educational attainment. In none of the estimated models, though, childcare availability turns out to have a statistically significant effect on the transition to the first child. How can we explain this gap between the apparent conceptual significance of non-parental childcare on the one hand, and the empirical insignificance of the availability of children's day care for a couple's decision to have a first child in western Germany on the other hand?

Despite distinct regional variations in the provision of slots in public day-care centers, the overall institutional constraints of childcare in the western states of the Federal Republic constitute a situation, where most women should perceive their individual chances to solve the 'compatibility problem' (HUININK 2001) as fairly bad even if informal care arrangements in social networks are taken into account as well. It probably takes a certain threshold of supply that needs to be reached, before parents consider the availability of day care as a parameter of their fertility decisions (see KRAVDAL 1996). Western German municipalities, however, are generally not even close to what might reasonably be considered as such a 'critical value' of childcare provision. 
Thus, more often than not, a choice must be made between having a child (and withdraw from the labor market), or to proceed an employment career (and remain childless).

Data on the ratio of childlessness and on the employment rate among western German mothers support this hypothesis. Among college educated women in western Germany, for instance, the ratio of childlessness amounts to almost 40 percent (DORBRITZ and SCHWARZ 1996: 244), which is entirely different from the situation in the US, where childcare is more readily available (RINDFUSS ET AL. 1996: 288). Moreover, there are only few western German mothers who are full-time employed. Even when the youngest child is of primary school age, only 10 percent of the western German mothers are in full-time employment (KONIETZKA and KREYENFELD 2001).

Both aspects clearly indicate that up to now public day-care providers have not met the actual needs of working mothers, but have rather kept their one-sided focus on the quality of care and children's education. To take into account the demand of prospective parents for more flexible childcare options and more extensive (full-time) care for children of all ages, a modernization of the German childcare system is urgently needed (see also KREYENFELD and HANK 2000: 334, KREYENFELD ET AL. 2001). 


\section{References}

Adler, M. A. (1997). Social change and decline in marriage and fertility in Eastern Germany. Journal of Marriage and the Family, 59(1), 37-49.

Ahn, N. \& Mira, P. (1999). A note on the changing relationship between fertility and female employment rates in developed countries. FEDEA Documento de Trabjo 9909.

Allison, P.A. (1982). Discrete-Time Methods for the Analysis of Event Histories. In S. Leinhardt (Ed.), Social Methodology (pp. 61-98). San Francisco.

Anderson, P. \& Levine, P. B. (2000). Child care and mothers' employment decisions. In D. Card \& R. Blank (Eds.), Finding Jobs: Work and Welfare Reform (pp.420462). New York.

Bertram, H. \& Dannenbeck, C. (1991). Familien in städtischen und ländlichen Regionen. In H. Bertram (Ed.), Die Familie in Westdeutschland (pp.79-110). Opladen.

Blau, D. M. \& Robins, P. K. (1989). Fertility, employment, and child-care costs. Demography, 26(2), 287-299.

Blau, D. M. \& Hagy, A.P. (1998). The Demand for Quality in Child Care. Journal of Political Economy, 106(1), 104-146.

Blossfeld, H.-P. \& Huinink, J. (1991). Human Capital Investments or Norms of Role Transition? How Women's Schooling and Career Affect the Process of Family Formation. American Journal of Sociology, 97(1), 143-168.

Bock, K. \& Timmermann, D. (2000). Wie teuer sind unsere Kindergärten? Neuwied: Luchterhand.

Brewster, K. L. \& Rindfuss, R. R. (2000). Fertility and women's employment in industrialized nations. Annual Review of Sociology, 26, 271-296.

Budig, M.J. \& England, P. (2001). The wage penalty for motherhood. American Sociological Review, 66, 204-225.

Bundesamt für Bauwesen und Raumordnung (BBR) (1999). Aktuelle Daten zur Entwicklung der Städte, Kreise und Gemeinden. Berichte (Vol. 3). Bonn.

Butz, W. P. \& Ward, M. P. (1979). The emergence of countercyclical U.S. fertility. American Economic Review, 69(3), 318-328.

Casper, L. \& O'Connell, M. (1998). Work, income, and married fathers as child care providers. Demography, 35(2), 243-250.

Colberg-Schrader, H. \& Zehnbauer, A. (1996). Rechtsanspruch auf einen Kindergartenplatz. Bedarfsplanung, Notlösungen, alternative Angebote. München: Deutsches Jugendinstitut. 
Conelly, R. (1992). The effect of child care costs on married women's labor force participation. The Review of Economics and Statistics, 74(1), 83-90.

DeWit, M. L. \& Ravanera, Z. R. (1998). The changing impact of women's educational attainment on the timing of births in Canada. Canadian Studies in Population, 25(1), 45-67.

Dorbritz, J. \& Schwarz, K. (1996). Kinderlosigkeit in Deutschland - ein Massenphänomen? Analysen zur Erscheinungsformen und Ursachen. Zeitschrift für Bevölkerungswissenschaft, 21(3), 231-261.

Ellingsæter, A.L. \& Rønsen, M. (1996). The Dual Strategy: Motherhood and the Work Contract in Scandinavia. European Journal of Population, 12(3), 239-260.

Engelbrech, G. \& Jungkunst, M. (1998). Erwerbsbeteiligung von Frauen und Kinderbetreuung in ost- und westdeutschen Familien. IAB Werkstattbericht 2/98.

England, P. \& Farkas, G. (1986). Households, Employment, and Gender: A Social, Economic, and Demographic View. New York.

Esping-Andersen, G. (1999). Social Foundations of Postindustrial Economics. Oxford.

Gordon, R.A. \& Chase-Lansdale, L.P. (2001). Availability of child care in the United States: a description and analysis of data sources. Demography, 38(2), 299-316.

Guo, G., \& Zhao, H. (2000). Multilevel Modeling for Binary Data. Annual Review of Sociology, 26, 441-462.

Gustaffson, S. \& Stafford, F. (1992). Child care subsidies and labor supply in Sweden. Journal of Human Resources, 27, 204-230.

Hank, K. (2001). Regional Social Contexts and Individual Fertility Decisions: A Multilevel Analysis of First and Second Births in Western Germany. MPIDR Working Paper WP 2001-015. Available http://www.demogr.mpg.de/Papers/Working/wp-2001-015.pdf.

Hank, K., Tillmann, K. \& Wagner, G.G. (2001). Außerhäusliche Kinderbetreuung in Ostdeutschland vor und nach der Wiedervereinigung. Ein Vergleich mit Westdeutschland in den Jahren 1990 - 1999. Zeitschrift für Bevölkerungswissenschaft, 26, forthcoming.

Heckman, J. J. \& Walker, J. R. (1990). The relationship between wages and income and the timing of births: Evidence from Swedish longitudinal data. Econometrica 58(6), 1411-1441.

Hirschman, Charles (1994). Why fertility changes. Annual Review of Sociology, 20, 203-233.

Hoem, B. (2000). Entry into motherhood in Sweden: the influence of economic factors on the rise and fall in fertility, 1986-1997. Demographic Research, 2(4). Available 
www.demographic-research.org/Volumes/Vol2/4.

Hox, J.J. \& Kreft, I.G.G. (1994). Multilevel Analysis Models. Sociological Methods \& Research, 22, 283-299.

Huinink, J. (2001). The Macro-Micro Link in Demography - Explanations of Demographic Change. Paper prepared for the EuroConference 'The Second Demographic Transition in Europe', Bad Herrenalb, June 23-28. Available http://www.demogr.mpg.de/Papers/workshops/010623_paper08.pdf.

Joshi, H. (1998). The opportunity costs of childbearing: More than mothers' business. Journal of Population Economics, 11(2), 161-183.

Kistler, E., Pfaff, A. B. \& Jaufmann, D. (1993). Aktuelle Daten zur Entwicklung der Kindereinrichtungen in den neuen Ländern. Es droht eine Abwärtsspirale. Arbeit und Sozialpolitik, 40(3-4), 49-54.

Konietzka, D. \& Kreyenfeld, M. (2001). Nichteheliche Geburten in Ostdeutschland in den 90er Jahren - Alte Gewohnheiten oder neue Familienformen? Paper prepared for the Annual Meeting of the Deutsche Gesellschaft für Demographie, Berlin, June 21-23.

Kravdal, Ø. (1996). How the local supply of day-care centers influences fertility in Norway: A parity-specific approach. Population Research and Policy Review, 15, 201-218.

Kreyenfeld, M. (2000). Changes in the Timing of First Birth in East Germany after ReUnification. Schmollers Jahrbuch, 120(2), 169-186.

Kreyenfeld, M. (2001). Women's education and second births in West Germany. An analysis of the birth cohorts 1956-1965 with data from the German Micro-Census. Mimeo. MPIDR Rostock.

Kreyenfeld, M., \& Hank, K. (2000). Does the availability of childcare influence the employment of mothers? Findings from western Germany. Population Research and Policy Review, 19(4), 317-337.

Kreyenfeld, M. \& Wagner, G. (2000). Die Zusammenarbeit von Staat und Markt in der Sozialpolitik: Das Beispiel Betreuungsgutscheine und Qualitäts-Regulierung für die institutionelle Kinderbetreuung. In W. Schmähl (Ed.), Soziale Sicherung zwischen Markt und Staat, Schriften des Vereins für Socialpolitik. Neue Folge (Vol. 275, pp.309-337).

Kreyenfeld, M., Spiess, C. K. \& Wagner, G.G. (2001). Finanzierungs- und Organisationsmodelle institutioneller Kinderbetreuung. Neuwied.

Lehrer, E.L. \& Kawasaki, S. (1985). Child Care Arrangements and Fertility: An Analysis of Two-Earner Households. Demography, 22(4), 499-513.

Lesthaeghe, R. (1995). The second demographic transition in Western countries: an interpretation. In K.O. Mason \& A-M. Jensen (Eds.), Gender and family change in 
industrialized countries (pp. 17-62). Oxford.

Macunovitch, D. J. (1996). A review of recent developments in the economics of fertility. In P. Menchik (Ed.), Household and Family Economics (pp.91-150). Boston: Kluwer Academic Publishers.

Mason, K.O. \& Kuhlthau, K. (1992). The Perceived Impact of Child Care Costs on Women'S Labor Supply and Fertility. Demography, 29(4), 523-543.

Merrigan, P. \& St.Pierre, Y. (1998). An econometric and neoclassic analysis of the timing and spacing of births in Canada from 1950 to 1990. Journal of Population Economics, 11(1), 29-51.

Meyers, M.K., Gornick, J.C. \& Ross, K.E. (1997). Public childcare, parental leave, and employment. In: D. Sainsbury (Ed.), Gender and Welfare State Regimes (pp.117146). Oxford.

Ott, N. (1992). Intrafamily bargaining and household decisions. Berlin et al..

Rindfuss, R. R. \& Brewster, K. L. (1996). Childrearing and fertility. Population and Development Review, 22(Suppl.), 258-289.

Rindfuss, R.R., Morgan, S.P. \& Offutt, K. (1996). Education and the changing age pattern of American fertility: 1963-1989. Demography, 33(3), 277-290.

SOEP Group (2001). The German Socio-Economic Panel (GSOEP) after more than 15 years - Overview. In E. Holst et al. (Eds.), Proceedings of the 2000 Fourth International Conference of German Socio-Economic Panel Study Users (GSOEP 2000) (pp.7-14), Vierteljahrshefte zur Wirtschaftsforschung, 70(1).

Spiess, K. (1998). Staatliche Eingriffe in Märkte für Kinderbetreuung. Frankfurt am Main.

Stolzenberg, R.M. \& Waite, L.J. (1984). Local labor markets, children and labor force participation of wives. Demography, 21(2), 157-170.

Tietze, W. \& Rossbach, H.-G. (1991). Die Betreuung von Kindern im vorschulischen Alter. Zeitschrift für Pädagogik, 37, 555-579.

Tietze, W., Rossbach, H.G. \& Roitsch, K. (1993). Betreuungsangebote für Kinder im vorschulischen Alter. Ergebnisse einer Befragung von Jugendämtern in den alten Bundesländern. Schriftenreihe des Bundesministeriums für Frauen und Jugend. Stuttgart: Kohlhammer.

Yamaguchi, K. (1991). Event History Analysis. Newbury Park. 


\section{Appendix}

Table 1: Use of public day care in Germany 1990, 1995, 1999 (in percent of the respective age group)

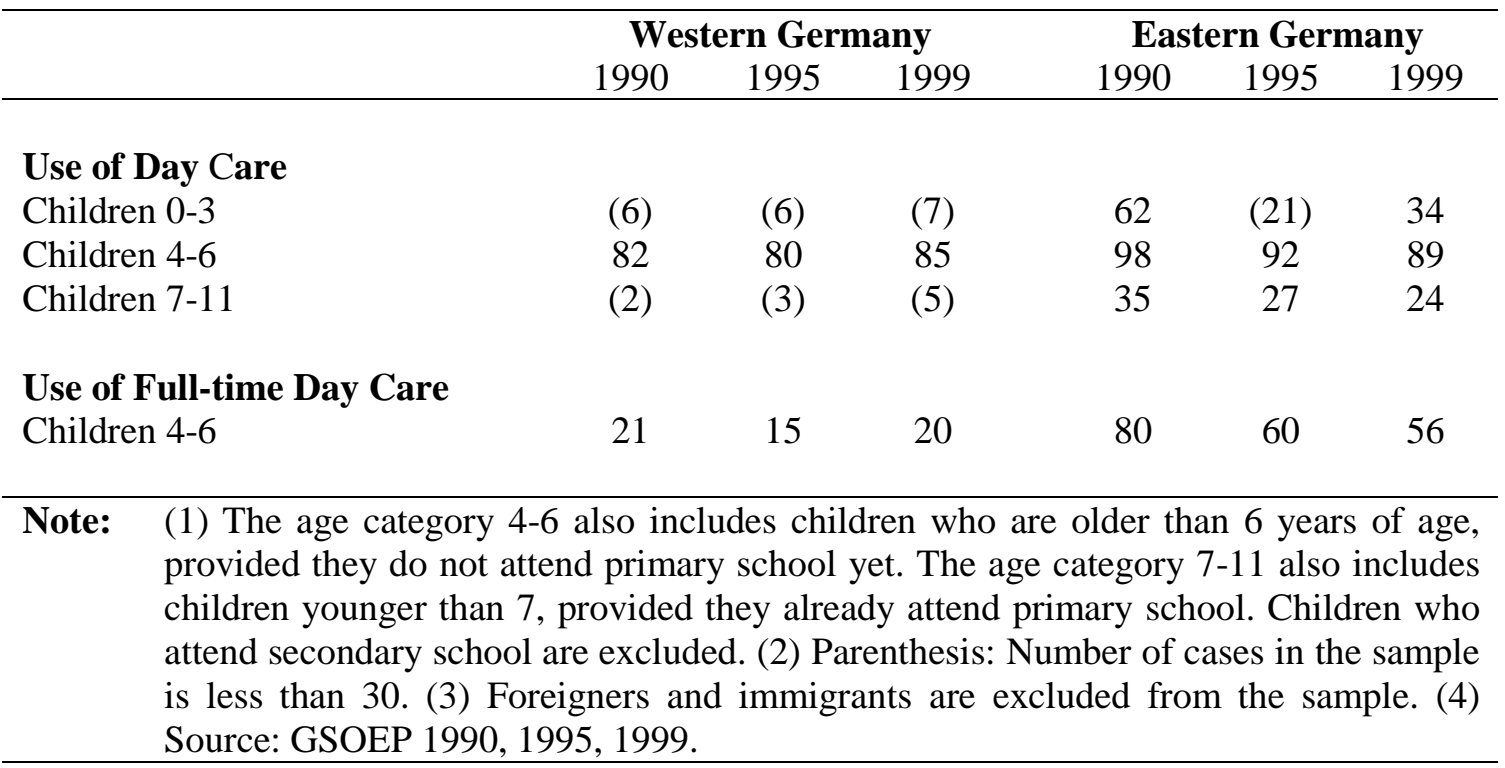

Table 2: Average monthly fees for public day care in Germany 1996 (in DM)

\begin{tabular}{|c|c|c|}
\hline & Western Germany & Eastern Germany \\
\hline Krippe & (130) & 130 \\
\hline Kindergarten & 130 & 110 \\
\hline - part-time & 110 & 110 \\
\hline - full-time & 150 & 120 \\
\hline Hort & 60 & $(80)$ \\
\hline \multicolumn{3}{|c|}{$\begin{array}{l}\text { Note: (1) When the fees were calculated, parents who do not pay at all for the use of public } \\
\text { day care (i.e., nine percent of the sample) were included. (2) Parenthesis: Number of } \\
\text { cases in the sample is less than } 30 \text { cases. (3) Sample weights were applied. (4) } \\
\text { Source: GSOEP 1996. }\end{array}$} \\
\hline
\end{tabular}


Table 3: Additional childcare arrangements for the youngest child in the household in 1997 (in percent)

\begin{tabular}{|c|c|c|c|c|c|c|}
\hline \multirow[b]{2}{*}{ Age of child } & \multicolumn{3}{|c|}{ Western Germany } & \multicolumn{3}{|c|}{ Eastern Germany } \\
\hline & $0-3$ & 4-6 & $7-11$ & 0-3 & 4-6 & $7-11$ \\
\hline \multicolumn{7}{|l|}{ All Mothers } \\
\hline Relatives & 37 & 41 & 24 & 39 & 32 & 37 \\
\hline Friends & 10 & 8 & 6 & 13 & 3 & 2 \\
\hline Paid care & 5 & 6 & 5 & 3 & 0 & 1 \\
\hline $\begin{array}{l}\text { No additional } \\
\text { care }\end{array}$ & 51 & 51 & 68 & 51 & 68 & 60 \\
\hline \multicolumn{7}{|c|}{ Working Mothers } \\
\hline Relatives & 52 & 52 & 30 & $*)$ & 49 & 40 \\
\hline Friends & 15 & 9 & 6 & *) & 5 & 2 \\
\hline Paid care & 7 & 7 & 6 & $*)$ & 0 & 1 \\
\hline $\begin{array}{l}\text { No additional } \\
\text { care }\end{array}$ & 29 & 38 & 60 & $*)$ & 51 & 57 \\
\hline $\begin{array}{l}\text { (1) } \mathrm{T} \\
\text { regula } \\
\text { size i } \\
\text { Germ }\end{array}$ & $\begin{array}{l}\text { tion } \\
\text { take } \\
\text { all to } \\
\text { (3) }\end{array}$ & $\begin{array}{l}\text { irvey } \\
\text { the } \\
\text { mea } \\
\text { GSOl }\end{array}$ & $\begin{array}{l}\text { re the } \\
\text { Multip } \\
1 \text { result } \\
7 .\end{array}$ & $\begin{array}{l}\text { ons o } \\
\text { vers } \\
\text { opul }\end{array}$ & $\begin{array}{l}\text { your } \\
\text { owed } \\
\text { nly h }\end{array}$ & $\begin{array}{l}\text { old who } \\
\text { Sample } \\
\text { dds with }\end{array}$ \\
\hline
\end{tabular}

Table 4: Descriptive sample statistics

\begin{tabular}{lc}
\hline \multicolumn{1}{c}{ Variable } & Mean (Stdv.) \\
\hline Occurrences (Number of births) & 836 \\
Age & $25.1(4.0)$ \\
Education & \\
In education & 0.17 \\
No degree & 0.18 \\
Vocational degree & 0.57 \\
University degree & 0.07 \\
Marital status & 0.28 \\
Foreigner & 0.23 \\
Childcare & \\
Family network available & 0.29 \\
Above average public day care (Krippe) & 0.63 \\
$N$ (regions) & 75 \\
$N$ (women) & 2,474 \\
$N$ (records) & 10,451 \\
\hline Note: (1) Standard deviations are not displayed for binary variables. (2) Source: GSOEP and \\
GSOEP-Geocode 1984-1995, authors' calculations.
\end{tabular}


Table 5: Results of (multilevel) discrete-time logistic regression. - Dependent variable: first birth. - Main effects only.

\begin{tabular}{|c|c|c|c|c|c|c|c|c|c|c|c|c|}
\hline & \multicolumn{4}{|c|}{ MODEL 1} & \multicolumn{4}{|c|}{ MODEL 2} & \multicolumn{4}{|c|}{ MODEL 3} \\
\hline & $\beta$ & $\exp (\beta)$ & $\mathrm{t}$ & & $\beta$ & $\exp (\beta)$ & $\mathrm{t}$ & Sig. & $\beta$ & $\exp (\beta)$ & $\mathrm{t}$ & Sig. \\
\hline Intercept & -8.69 & 0.00 & -4.82 & $* * *$ & -8.51 & 0.00 & -4.70 & $* * *$ & -8.56 & 0.00 & -4.73 & $* * *$ \\
\hline \multicolumn{13}{|l|}{ Age } \\
\hline Age & 0.42 & 1.52 & 3.11 & $* * *$ & 0.41 & 1.51 & 3.03 & $* * *$ & 0.41 & 1.51 & 3.01 & $* * *$ \\
\hline Age squared & -0.01 & 0.99 & -3.55 & $* * *$ & -0.01 & 0.99 & -3.43 & $* * *$ & -0.01 & 0.99 & -3.41 & $* * *$ \\
\hline \multicolumn{13}{|l|}{ Education } \\
\hline In education & -0.77 & 0.46 & -3.82 & $* * *$ & -0.76 & 0.47 & -3.73 & $* * *$ & -0.76 & 0.47 & -3.72 & $* * *$ \\
\hline No degree & 0.03 & 1.03 & 0.24 & & 0.06 & 1.06 & 0.55 & & 0.06 & 1.06 & 0.55 & \\
\hline Vocational degree & 0 & & & & 0 & & & & 0 & & & \\
\hline University degree & 0.22 & 1.25 & 1.48 & & 0.27 & 1.31 & 1.75 & $*$ & 0.25 & 1.29 & 1.66 & * \\
\hline \multicolumn{13}{|l|}{ Marital status } \\
\hline Married & 2.64 & 14.00 & 26.8 & $* * *$ & 2.61 & 13.57 & 26.4 & $* * *$ & 2.61 & 13.61 & 26.5 & $* * *$ \\
\hline Not married & 0 & & & & 0 & & & & 0 & & & \\
\hline \multicolumn{13}{|l|}{ Nationality } \\
\hline Foreigner & 0.12 & 1.13 & 1.21 & & 0.13 & 1.14 & 1.34 & & 0.13 & 1.14 & 1.32 & \\
\hline German & 0 & & & & 0 & & & & 0 & & & \\
\hline \multicolumn{13}{|l|}{ Family network } \\
\hline $\begin{array}{l}\text { Grandparents live in } \\
\text { same town }\end{array}$ & -- & -- & -- & & 0.04 & 1.04 & 0.47 & & 0.04 & 1.04 & 0.45 & \\
\hline $\begin{array}{l}\text { Grandparents do not live } \\
\text { in same town }\end{array}$ & & & & & 0 & & & & 0 & & & \\
\hline \multicolumn{13}{|l|}{$\begin{array}{l}\text { Public day care } \\
\text { (Krippe) }\end{array}$} \\
\hline $\begin{array}{l}\text { Above average } \\
\text { provision }\end{array}$ & -- & -- & -- & & -- & -- & -- & & 0.11 & 1.12 & 1.38 & \\
\hline $\begin{array}{l}\text { Below average } \\
\text { provision }\end{array}$ & & & & & & & & & 0 & & & \\
\hline Regional random effect & & & & & & & & & & & & \\
\hline$\sigma_{\mathrm{u}}$ & -- & -- & -- & & -- & -- & -- & & 0.00 & 1.00 & & \\
\hline
\end{tabular}


Table 6: Results of multilevel discrete-time logistic regression. - Dependent variable: first birth. - Interaction variables only.

\begin{tabular}{llllll}
\hline$\beta$ & $\exp (\beta)$ & $\mathrm{t}$ & Sig. \\
\hline
\end{tabular}

\section{MODEL 4}

\section{Education \&}

\section{Family network}

In education

$-0.76$

0.47

$-3.76$

$* * *$

No degree

0.06

1.06

0.54

Vocational degree

University \& Network

0.31

1.36

1.16

University \& No network

0.23

1.26

1.28

Public day care (Krippe)

Above average provision

0.12

1.12

1.38

Below average provision

$$
0
$$

MODEL 5

\section{Education \&}

Public day care (Krippe)

In education

$-0.76$

0.47

$-3.76$

0.54

No degree

0.06

1.06

Vocational degree

0

University \& Above average

0.29

1.33

1.33

provision

University \& Below average

0.22

1.24

0.82

provision

\section{Family Network}

Grandparents live in

$$
0.04
$$

1.04

0.47

same town

Grandparents do not live in 